\title{
UPAYA MENINGKATKAN HASIL BELAJAR MATEMATIKA MENGGUNAKAN MODEL PEMBELAJARAN BERBASIS DENGAN MEDIA KONKRET PADA PESERTA DIDIK KELAS IV SDN-3 TELANGKAH TAHUN PELAJARAN 2016/2017
}

\author{
OLEH : Repitae*, Ade Salahudin Permadi**
}

\begin{abstract}
ABSTRAK
Penelitian ini bertujuan untuk : (1) mendeskripsikan aktivitas belajar peserta didik dalam pembelajaran Matematika menggunakan model pembelajaran berbasis masalah dengan media konkret; (2) meningkatkan hasil belajar Matematika menggunakan pembelajaran berbasis masalah dengan media konkret pada peserta didik kelas IV SDN-3 Telangkah.

Metode dan jenis penelitian yang digunakan dalam penelitian ini adalah Penelitian Tindakan Kelas (PTK). Subjek dalam penelitian ini adalah peserta didik kelas IVA SDN-3 Telangkah yang berjumlah 32 orang. Teknik pengumpulan data dalam penelitian ini yaitu Observasi dan Tes. Sedangkn teknik analisis data menggunakan analisis kulitatif dan analisis kuantitatif.

Hasil penelitian menunjukkan bahwa : (1) Aktivitas belajar peserta didik selama pembelajaran Matematika menggunakan model pembelajaran berbasis masalah dengan media konkretmenjadi baik. Hal tersebut sesuai dengan data observasi yakni, pada siklus I memperoleh skor rata-rata 3,4 dengan kriteria baik. (2) Ada peningkatan hasil belajar peserta didik dalam kegiatan pembelajaran menggunakan model pembelajaran berbasis masalah dengan media konkret pada pelajaran Matematika yang menunjukkan pada pra tindakan dengan rata-rata 58 dengan presentase $47 \%$. Dan ada peningkatan siklus I dengan rata-rata 92dengan presentase $100 \%$ dengan klasifikasi tercapai.
\end{abstract}

Kata Kunci : Aktivitas, Hasil Belajar, Berbasis Masalah, Media Konkret, Matematika

\section{PENDAHULUAN}

Sekolah Dasar merupakan tempat sumber daya manusia untuk mengembangkan kemampuan, keahlian dan keterampilannya dalam menguasai suatu konsep mata pelajaran yang diprogramkan dalam suatu sekolah khususnya pelajaran Matematika.
Mata pelajaran Matematika perlu diberikan kepada semua peserta didik mulai dari sekolah dasar untuk membekali peserta didik dengan kemampuan berpikir logis, analitis, sistematis, kritis dan kreatif, serta kemampuan bekerjasama.

Peneliti menggunakan model pembelajaran berbasis masalah dengan berbantuan media konkret dalam 
pembelajaran Matematika guna membuat peserta didik lebih aktif dan mudah dalam memahami materi Matematika. Model pembelajaran berbasis masalah dapat melatih kemampuan berpikir peserta didik dalam memecahkan masalah yang terjadi dalam kehidupan sehari-hari menggunakan Matematika. Dalam penerapan model tersebut peneliti menggunakan media konkret dikarenakan dapat dilihat, disentuh dan mudah dibuat oleh peserta didik menggunakan barangbarang yang sudah tidak terpakai.

Saat peneliti melakukan observasi pada hari selasa, tanggal 17 Januari 2017 di kelas IVA SDN-3 Telangkah diketahui masih ada peserta didik yang memperoleh nilai dibawah rata-rata standar ketuntansan dari sekolah. Dari seluruh peserta didik pada kelas IVA SDN-3 Telangkah yang berjumlah 32 orang peserta didik dari 30\% atau sebanyak (10 orang peserta didik) yang memperoleh nilai di atas standar. Sedangkan $70 \%$ atau sebanyak (22 orang peserta didik) memperoleh nilai di bawah standar ketuntasan (KKM). Adapun standar ketuntasan yang telah ditentukan oleh sekolah untuk mata peajaran matematika yaitu 60. Data ini diperoleh melalui wawancara dengan wali kelas IVA dan hasil ulangan harian Matematika.

Peneliti menggunakan model pembelajaran berbasis masalah dengan berbantuan media konkret dalam pembelajaran Matematika guna membuat peserta didik lebih aktif dan mudah dalam memahami materi Matematika. Model pembelajaran berbasis masalah dapat melatih kemampuan berpikir peserta didik dalam memecahkan masalah yang terjadi dalam kehidupan sehari-hari menggunakan Matematika. Dalam penerapan model tersebut peneliti menggunakan media konkret dikarenakan dapat dilihat, disentuh dan mudah dibuat oleh peserta didik menggunakan barangbarang yang sudah tidak terpakai. Oleh karena itu, peneliti mencoba menggunakan model dan media tersebut untuk meningkatkan hasil belajar pada mata pelajaran Matematika agar mencapai standat Kriteria Ketuntasan Minimal (KKM) yang ditetapkan oleh SDN-3 Telangkah.

Berdasarkan fenomena yang terjadi pada uraian di atas maka peneliti tertarik untuk melakukan penelitian tindakan kelas dengan judul "Upaya Meningkatakan Hasil Belajar Matematika Menggunakan Model Pembelajaran Berbasis Masalah Dengan Media Konkret Pada Peserta Didik Kelas IV SDN-3 Telangkah Tahun Pelajaran 2016/2017".

Belajar adalah berusaha memperoleh kepandaian atau ilmu, berlatih, berubah tingkah laku atau tanggapan yang disebabkan oleh pengalaman. Menurut W.S. Winkel (Ahmad Susanto, 2013:4) mengemukakan bahwa:

Belajar adalah suatu aktivitas yang berlangsung dalam interaksi aktif antara seseorang dengan lingkungan, dan menghasilkan perubahanperubahan dalam pengetahuan, pemahaman, keterampilan dan nilai sikap yang bersifat relatif konstan dan berbekas.

Menurut Mills (Agus Suprijono, 2009 : 45) berpendapat bahwa :

Model pembelajaran adalah bentuk presentasi akurat sebagai proses aktual yang memungkinkan seseorang atau sekelompok orang mencoba bertindak berdasarkan model itu.

Dari pendapat di atas, dapat disimpulkan bahwa melalui model pembelajaran, guru 
dapat membantu peserta didik mendapatkan informasi, ide, keterampilan, cara berpikir, dan mengekspresikan ide. Model pembelajaran berfungsi pula sebagai pedoman bagi para perancang pembelajaran dan para guru dalam merencanakan aktivitas belajar mengajar agar mencapai tujuan pembelajaran secara maksimal.

Pembelajaran berbasis masalah merupakan salah satu model pembelajaran inovatif yang dapat memberikan kondisi belajar aktif pada peserta didik. Menurut Duch (Yatim Riyanto, 2012:285) menyatakan bahwa :

Pembelajaran berbasis masalah adalah suatu model pembelajaran yang menghadapkan peserta didik pada tantangan "belajar untuk belajar".

Media pembelajaran diartikan sebagai semua benda yang menjadi perantara yang tejadi dalam pembelajaran. Kegiatanpembelajaran dilaksanakan setiap hari merupakan kehidupan di suatu kelas, di mana pendidik dan peserta didik saling terkait dalam pelaksanaan kegiatan pembelajaran yang telah direncanakan oleh pendidik. Oleh karena itu, pendidik harus mampu membuat suasana pembelajaran lebih menarik supaya peserta didik tertarik, tidak merasa bosan dan jenuh serta dapat memahami materi yang diajarkan dengan mudah.

Media konkret adalah benda-benda yang dapat menjadi perantara untuk menyampaikan pesan melalui pembelajaran dari guru kepada peserta didik. Media pembelajaran yang dapat diamati secara langsung oleh panca indra dan dapat ditemukan dengan mudah karena berada di sekitar guru maupun peserta didik.
Dalam pembelajaran Matematika, setiap konsep yang abstrak atau yang baru dipahami oleh peserta didik perlu segera diberi penguatan agar dapat tersimpan dan bertahan lama di memori peserta didik. Salah satunya dengan menggunakan media pada pembelajaran Matematika, dengan media penyampaian materi menjadi lebih praktis dan yang paling penting membawa peserta didik berpikir kritis. Dengan begitu peserta didik dengan sendirinya akan memiliki keterampilan dalam menggunakan konsep-konsep matematika dalam kehidupan sehari-hari yang merupakan tujuan akhir dari pembelajaran Matematika.

Pecahan dapat diartikan sebagai bagian dari sesuatu yang utuh. Dalam ilustrasi gambar, bagian yang dimaksud adalah bagian yang diperhatikan, yang biasanya ditandai dengan arsiran. Bagian inilah yang dinamakan pembilang. Adapun bagian yang utuh adalah bagian yang dianggap sebagai satuan, dan dinamakan penyebut. Menurut Depdikbud 1999 (Heruman, 2014:43) menyatakan bahwa : Pecahan merupakan salah satu topik yang sulit untuk diajarkan. Kesulitan itu terlihat dari kurang bermaknanya kegiatan pembelajaran yang dilakukan guru, dan sulitnya pengadaan media pembelajaran. Akibatnya, guru biasa langsung mengajarkan pengenalan angka, seperti pada pecahan $\frac{1}{2}, 1$ disebut pembilang dan 2 disebut penyebut.

\section{METODE PENELITIAN}

Penelitian ini dilaksanakan menggunakan rancangan Penelitian Tindakan Kelas (PTK). Seperti yang diungkapkan Kemmis dan McTaggart (Ishak Abdulhak dan Ugi Suprayogi, 
2013:92) bahwa secara khusus pengertian penelitian tindakan dalam bidang pendidikan sebagai berikut : :

Secara sederhana, penelitian
tindakan dapat didefinisikan
sebagai sebuah proses investigasi
terkendali yang bersiklus dan
bersifat reflektif mandiri yang
dilakukan oleh tenaga dan
pengelola kependidikan yang
memiliki tujuan untuk melakukan
perbaikan-perbaikan terhadap
sistem, cara kerja, proses, isi,
kompetensi, atau situasi
pembelajaran.

Peran dan partisiasi peneliti dalam penelitian sangatlah penting karena peneliti berperan sebagai perencana, pelaksana kegiatan, pengamat serta sebagai pelapor hasil penelitian. Sebagai pelaksana tindakan, peneliti bertindak sebagai pengajar atau pendidik yang bertugas membuat Rencana Pelaksanaan Pembelajaran (RPP) sekaligus menyampaikan bahan ajar yang akan diberikan selama proses pembelajaran. Peneliti berkolaborasi dengan guru kelas untuk berperan sebagai pengamat (observer) yang bertugas mengobservasi kegiatan selama proses pembelajaran berlangsung.

Subjek dari penelitian adalah seluruh peserta didik kelas IVA SDN-3 Telangkah. Jumlah peserta didik sebanyak 32 orang, terdiri dari 17 orang perempuan dan 15 orang laki-laki

Rancangan Penelitian Tindakan

Kelas (PTK) yang dicirikan dengan adanya siklus-siklus, setiap silkus terdiri dari empat tahap yaitu perencanaan, pelaksanaan tindakan, observasi dan refleksi.

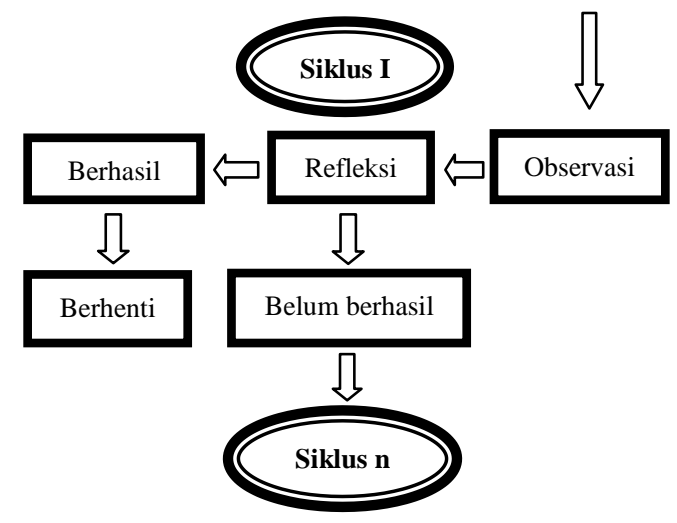

Gambar 2. Rancangan Penelitian Tindakan Kelas
Model : Kurt Lewin
Sumber : Paizaluddin \& Ermalinda (2014:30)

Sedangkan, menurut Stephen Kemmis dan Robin Mc Taggart (Samsu Sumadayo, 2013:39) terdiri dari empat komponen, yaitu (1) Perencanaan (planing), (2) Aksi/Tindakan (action), (3) Observasi (observing) dan (4) Refleksi (reflecting).

Pengumpulan data yang digunakan dalam penelitian ini yaitu menggunakan observasi (pengamatan) mengenai aktivitas peserta didik dalam pembelajaran dan tes yang gunkan untuk mengukur kemampuan peserta didik (tes hasil belajar).

\section{HASIL DAN PEMBAHASAN}

1. Hasil Pengamatan Aktivitas Guru Dan Peserta Didik

Aktivitas belajar peserta didik pada proses pembelajaran Matematika dengan menggunakan model pembelajaran berbasis masalah dengan media konkret pada SDN-3 Telangkah tahun pelajaran 2016/2017, menunjukkan bahwa aktivitas peserta didik lebih bersemangat pada siklus I. Hal ini dapat dibuktikan dari aktivitas rata-rata yang diperoleh peserta didik 
pada siklus I adalah 3,4 atau dalam kategori baik.

\section{Grafik 1}

Aktivitas Guru dan Aktivitas

Belajar Peserta Didik

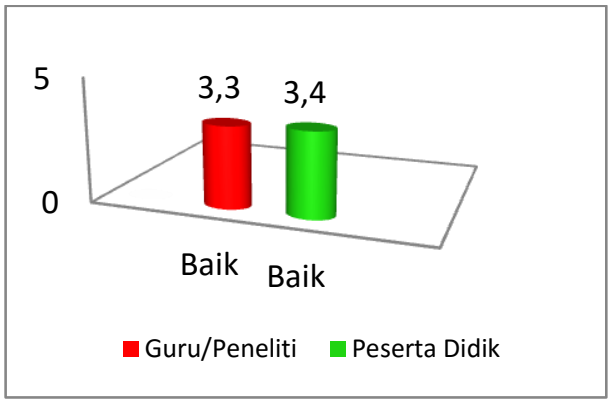

\section{Hasil Belajar Peserta Didik}

Hasil belajar yang diperoleh berdasarkan hasil tes pada peserta didik kelas IV SDN-3 Telangkah yang menggunkan model pembelajaran berbasis masalah dengan media konkret dapat terlihat dari grafik di bawah ini :

Grafik 2

Peningkatan Hasil Belajar Secara Klasikal

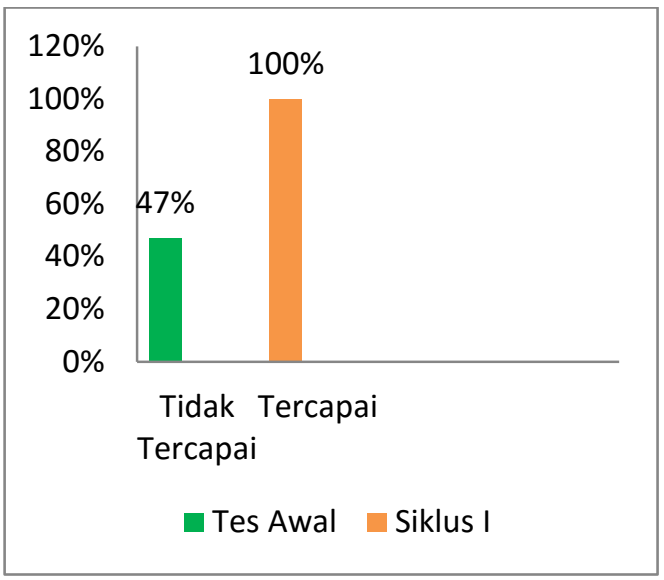

Berdasarkan grafik di atas, dapat dilihat bahwa ada peningkatan hasil belajar peserta dalam kegiatan pembelajaran pada siklus I menggunakan model pembelajaran berbasis masalah dengan media konkret pada pelajaran Matematika materi menyelesaikan masalah pecahan pada kelas IVA SDN-3 Telangkah tahun pelajaran 2016/2017. Hal ini dapat dibuktikan dari hasil belajar yang mereka peroleh. Berdasarkan indikator ketercapaian hasil belajar setiap peserta didik dari mulai pra tindakan sampai siklus I yang diperoleh peserta didik mengalami peningkatan secara signifikan. Pra tindakan dengan ratarata 58 dengan presentase $47 \%$ dalam klasifikasi tidak tercapai. Sedangkan pada siklus I dengan rata-rata 92dengan presentase $100 \%$ dengan klasifikasi tercapai.

\section{SIMPULAN}

Berdasarkan hasil penelitian dan pembahasan dalam Penelitian Tindakan Kelas (PTK) yang didapat peneliti selama penelitian dilakukan di SDN-3 Telangkah di kelas IVA adalah sebagai berikut :

1. Aktivitas belajar peserta didik selama pembelajaran Matematika dengan menggunakan model pembelajaran berbasis masalah dengan media konkret baik. Hal tersebut sesuai dengan data observasi yakni, pada siklus I memperoleh skor rata-rata 3,4 dengan kriteria baik. Berdasarkan hasil tersebut dapat disimpulkan bahwa peserta didik merespon terhadap kegiatan pembelajaran yang dilakukan dengan menggunakan model pembelajaran berbasis masalah dengan media konkret.

2. Ada peningkatan hasil belajar peserta dalam kegiatan pembelajaran menggunakan model pembelajaran berbasis masalah dengan media konkretpada pelajaran Matematika materi menyelesaikan masalah 
pecahan pada kelas IVA SDN-3 Telangkah tahun pelajaran 2016/2017. Hal ini dapat dibuktikan dari hasil belajar yang mereka peroleh. Pada pra tindakan dengan rata-rata 58 dengan presentase $47 \%$ (15 orang peserta didik memperoleh nilai $\geq 60$ dari 32 orang jumlah peserta didik kelas IVA sedangkan 17 orang peserta didik masih memperoleh <60) dalam klasifikasi tidak tercapai. Dan ada peningkatan, siklus I mengalami peningkatan dengan rata-rata 92dengan presentase $100 \%$ dengan klasifikasi tercapai dari 32 orang peserta didik mendapatkan nilai di atas $\geq 60$ sehingga siklus I dinyatakan tuntas dari klasikal yang diharapakan di tempat penelitia di atas $85 \%$.

\section{DAFTAR PUSTAKA}

Abdulhak, I., \& Suprayogi, U., (2013), Penelitian Tindakan Kelas DalamPendidikan Nonformal, Jakarta : PT. RajaGrafindo Persada

Heruman, (2014), Model Pembelajaran Matematika Di Sekolah Dasar, Bandung : PT. Remaja Rosdakarya

Riyanto, Y., (2012), ParadigmaPembelajaran Baru, Jakarta : Kencana

Sumadayo, S., (2013), Penelitian

Tindakan Kelas (PTK), Yogyakarta :

Graha Ilmu

Suprijono, A, (2009), CooperativeLaerning, Yogyakarta : Pustaka Pelajar
Susanto,A., (2013), Teori Belajar Dan Pembelajaran Di Sekolah Dasar, Jakarta : Kencana 